Research Article

\title{
Organic Farming Practices using EM-Technology in Malakand Division- Khyber Pakhtunkhwa
}

\section{Ayesha Khan ${ }^{1 *}$, Asmatullah ${ }^{2}$, Urooba Perviaz ${ }^{1}$, Khalid Nawab $^{1}$ and Mahmood Iqbal ${ }^{1}$}

${ }^{1}$ Department of Agricultural Extension Education and Communication, Faculty of Rural Social Sciences, The University of Agriculture Peshawar, Khyber Pakbtunkhwa, Pakistan; ${ }^{2}$ Technical Sales Officer (TSO), FMC Agricultural Solutions, Pakistan.

Abstract | The study investigates the efficacy of EM-Technology application through fermenter on fertilizers usage and irrigation of selected crops. Organic farming is the dire need of the day; to overcome the excessive use of chemical fertilizers alternative methods are adopted to decrease use of fertilizers. One of the techniques for organic farming is EM-Technology. EM-Technology is used in addition with animal manure and other organic wastes effectively in agriculture. The universe of the study was Malakand division of Khyber Pakhtunkhwa. The EM-Technology using 128 farmers' data were gathered from the District Director Agriculture of six districts. Each farmer was interviewed face to face to collect accurate information of EM-Technology used through fermenter. Majority of the farmers $93.8 \%$ were provided the EM-Bioaab solution by extension department. The extension department provided training to $96.1 \%$ farmers on formation of Extended-Bioaab from Basic-Bioaab. The results of t-test show a highly significant difference in use of fertilizer and number of irrigations before and after EM technology application as $\mathrm{P} \leq 0.01$. On average tomato crop showed a decline of 2.151 bags ha $^{-1}, 2.103$ bags ha $^{-1}$ in whereas 1.00 bags ha $^{-1}$ decline was observed in wheat. However, 1.685 decrease is recorded in onion while tomato and wheat showed a decrease of 1.509 and 1.200 in number of irrigations respectively. Farmers opined that FYM application through fermenter is easy and is equally distributed in the field. Results accomplish that decreasing trend was observed for all the crops regarding fertilizer usage and number of irrigations after using EM technology through fermenter. The study recommends the provision of information and awareness regarding EM technology to the farming communities to achieve the benefits of increased production, decrease in fertilizer usage and number of irrigations and to minimize environmental and health hazards.

Received | March 30, 2021; Accepted | November 19, 2021; Published | December 22, 2021

*Correspondence | Ayesha Khan, Department of Agricultural Extension Education and Communication, Faculty of Rural Social Sciences, The University of Agriculture Peshawar, Khyber Pakhtunkhwa, Pakistan; Email: ayesha@aup.edu.pk

Citation | Khan, A., Asmatullah, U. Perviaz, K. Nawab and M. Iqbal. 2021. Organic Farming practices using EM-Technology in Malakand Division- Khyber Pakhtunkhwa. Pakistan Journal of Agricultural Research, 34(4): 846-853.

DOI | https://dx.doi.org/10.17582/journal.pjar/2021/34.4.846.853

Keywords | EM-Technology, EM-Bioaab, Organic farming, Fermenter technology, Fertilizer use, Number of irrigation, Farm yard manure

\section{Introduction}

$\mathrm{O}$ rganic material was the primary source to enhance soil structure and production prior to chemical fertilizer introduction (Shaharoona and Arshad, 2003). The rigorous use of chemical fertilizers began with the Green Revolution (1950) which gained extensive acceptance due to remarkable increase in crop yields as compared to conventional organic methods (Braun and Roy, 1983). It initiated the era of synthetic fertilizers as a valuable alternate due to its ready source of nutrients; farmers deserted the use of organic matter. Previous researches has shown that application of synthetic fertilizer, pesti- 
cides/insecticides had decreased soil fertility, inhibited growth of beneficial microorganisms and caused human health hazards (Erisman et al., 2001) and its continuous use may cause human health problems and environmental issues (Ayoola and Makinde, 2007).

Deterioration of agricultural lands' physical and biological health took place because of intensive use of synthetic inorganic fertilizers, herbicides and insecticides. Organic farming is a technique of producing valued crop yield without causing hazards to the environment. The use of organic manures help in enhancing soil configuration, boosts soil organic carbon and bacterial biomass (Suresh et al., 2004). Microorganism can help eradicate the hurdles related with the use of chemical fertilizers and various pesticides, becoming more prominent in organic farming (Higa, 1991).

As a substitute to agrichemicals (chemical fertilizers and pesticides), the concept and technology of Effective Microorganism (EM) was developed by Professor Dr. Teruo Higa (1980), University of the Ryukyus, Okinawa, Japan, which was helpful in replacing agrichemicals. EM is an abbreviation of Effective Microorganisms also known as beneficial microorganism (BM); is a technology that applies effective microorganism i.e. a blend of various microorganisms having a revitalizing action on humans, plants and animals along with the natural environment (Gomiero et al., 2011). BM contains mixed culture of various beneficial and naturally occurring microorganisms mostly found in food produced by natural fermentation process and applied as inoculants to soil to increase the microbial diversity which improves soil health, growth, quality and yield of crops (Higa and Wididana, 1991; Asmatullah et al., 2019).

EM is ecofriendly as an organic liquid concentrate of distinct microbes mutually combined to produce beneficial effect on environment (Bhoyar et al., 2013) and cost effective due to waste recycling in the field promoting germination and growth, flowering, fruiting and ripening in crops (Higa, 2000). EM enhances photosynthetic ability of plants, increases efficiency of organic matter as fertilizer and nutrients availability (Rashid et al., 2016) and develops resistance against pests and diseases. It improves soil physical, chemical and biological environment and suppresses soil borne pathogens and pests (Kumar and Verma, 2019; Jalal et al., 2020: Bhoyar et al., 2013; and http://www. pakissan.com).
According to Bhoyar et al. (2013) the principal microorganisms in EM are:

1. Photosynthetic Bacteria (Rhodopseudomonas spp.)

2. Lactic acid bacteria (Lactobacillus spp.) and

3. Yeast

$\mathrm{BM}$ is a combination of selected microorganisms comprising major portion of lactic acid, bacteria and yeast, and small portion of photosynthetic bacteria, actinomycetes. Adding BM to field induces microbial activity and enhances decomposition process thus improves soil physical and chemical structure and properties effecting growth, yield and quality of crops (Meihoefer, 2000; Bhoyar et al., 2013). EM when combined both with farm yard manure and with synthetic fertilizer gave high yield, improved growth and dietary value of mung bean (Javaid and Bajwa, 2010).

Biofertigation is the process of applying fertilizer with irrigation water while; fermenter is a structure/ technique which ferments organic manures in a tank attached to water course and irrigation water passing through it mixes the organic nutrients of the tank with irrigation water. In agriculture farm yard manure is used to boost the retaining power of soil, decrease the use of synthetic fertilizer, making agriculture more economical and environment friendly (Whalen et al., 2003; Xiao et al., 2006). Mostly farmers in Pakistan store and stock animal manure along roadside or in the field, lying open in air and under sun for long duration causing nitrogen present in manure to escape as ammonia gas due to oxidative decomposition process. However, if the same manure is stored for a few days in fermenter tank, the microbes in bioaab converts it into amino acids through anaerobic fermentation. This fermented material in fermenter goes to the field automatically, with each irrigation, spreading equally the slurry layer after layer (Hussain et al., 2002).

In 1990 trials of nature farming with EM technology began in Pakistan, which was developed at Nature Farming Research Center (NFRC), Faisalabad by an eminent scientist Dr. Tahir Hussain, and is now available as EM-Bioaab, EM-Biovet and EM-Biocontrol (Hussain et al., 1992; Shaheen et al., 2017). EM-Bioaab is used in agricultural crops along with organic manures as alternate to chemical fertilizers (Hussain et al., 2002) but organic matters alone cannot act as a substitute for synthetic fertilizers, and fulfill the 
nutrients requirement of plant (Khanam et al., 2001; Alam et al., 2005, Namasivayam and Kirithiga, 2010). The BM in inoculation with organic nitrogen sources decrease expenditure on inputs and boost agriculture income (Muhammad et al., 2014).

The "Establishment and Dissemination of Fermentation Technology for Organic Farming in Khyber Pakhtunkhwa" was initiated in 2013-14 by the government of Khyber Pakhtunkhwa (KP) in almost all divisions. This activity was also launched in Malakand division (Draft PC1, 2013-14). In the current study efforts were made to investigate the effects of EM-Technology use in inoculation with farm yard manure through fermenter for organic farming on fertilizers usage and number of irrigations of selected crops in Malakand division. No such work is done on organic farming evaluation in the study area, so this is an effort to highlight the efficiency of EM technology via fermenter for organic farming.

\section{Objectives}

1. To study the effects of EM-Technology through fermenter on fertilizer use and number of irrigation of selected crops in the study area.

2. To highlight the reasons for adopting EM-Technology through fermenter in the study area.

\section{Hypothesis}

1. $\mathrm{H}_{0}=$ Application of EM technology through fermenter has no effect on fertilizer use of selected crops.

2. $\mathrm{H}_{1}=$ Application of EM technology through fermenter has effect on fertilizer use of selected crops.

3. $\mathrm{H}_{0}=$ Application of EM technology through fermenter has brought no difference in number of irrigation of selected crops.

4. $\mathrm{H}_{1}=$ Application of EM technology through fermenter has brought difference in number of irrigation of selected crops.

\section{Materials and Methods}

\section{Sampling procedure}

This study was conducted in Malakand division of Khyber Pakhtunkhwa. The research area is geographically located at $35^{\circ} \mathrm{N}$ latitude and $72^{\circ} \mathrm{E}$ longitude. Purposively six districts out of seven were selected on the basis of installation of fermenter in the area by agriculture extension department. In the select- ed districts of Malakand division 128 farmers using EM technology through fermenter were reported by the department of agriculture extension. Thus, all of 128 farmers using EM through fermenter were the respondents of the study. When each and every item in the universe is selected for the data collection it is called as census method or complete enumeration survey method. The census method can be used when universe is not vast, enough time and finance is available for data collection and higher degree of accuracy is required.

\section{Data collection and analysis}

For data collection, the farmers were interviewed using a well-developed and pre-tested interview schedule. Statistical Package for Social Sciences (SPSS) was used to analyze the data and results were presented in counts and percentages. For eliciting the difference brought by EM technology in fertilizer use and number of irrigations of the selected crops, a paired sample t-test was used. The formula used is given below;

$$
t=\frac{\Sigma d}{\sqrt{\frac{n\left(\Sigma d^{2}\right)-(\Sigma d)^{2}}{n-1}}}
$$

\section{Results and Discussion}

\section{Provision of EM-Bioaab}

EM-Bioaab has incredible ability to compost all types of crop residues, FYM, green and poultry manure, sugarcane filter cakes and even any biodegradable material through fermentation process to a high quality bio-fertilizer in few days. Bioaab is placed in a room or in dark with closed lid avoiding sunlight. It can be used up to one year or till no bed smell.

EM-Bioaab is a microbial mixture that can convert organic manures and residues to a high quality biofertilizer (Hussain et al., 2002) which is available with agro input dealers. Data regarding provision of Bioaab solution to the farmers is presented in Table 1. Agriculture extension department provided Bioaab solution to majority i.e. 120 (93.8\%) farmers while 8 (6.2\%) farmers purchased it from market. Similar findings were reported by Ali and Haider (2012) where agricultural inputs like modern machinery, seed and Bioaab with means 2.733, 2.689 and 2.574 respectively were provided to farmers by agriculture extension department. 
Table 1: Provision of EM-Bioaab solution to the farmers.

\begin{tabular}{llll} 
Districts & \multicolumn{2}{l}{$\begin{array}{l}\text { Provision of EM-Bioaab } \\
\text { Extension Depart- }\end{array}$} & Purchased from \\
& $\begin{array}{l}\text { Tont No. (\%) } \\
\text { market No. (\%) }\end{array}$ & \\
Swat & $25(19.5)$ & $2(1.6)$ & $27(21.1)$ \\
Malakand & $28(21.9)$ & $2(1.6)$ & $30(23.4)$ \\
Lower Dir & $23(18.0)$ & $1(.8)$ & $24(18.8)$ \\
Upper Dir & $12(9.4)$ & $1(.8)$ & $13(10.2)$ \\
Buner & $23(18)$ & $1(.8)$ & $24(18.8)$ \\
Shangla & $9(7.0)$ & $1(.8)$ & $10(7.8)$ \\
Total & $120(93.8)$ & $8(6.2)$ & 128
\end{tabular}

Table 2: Farmers training of making Extended-Bioaab solution.

$\begin{array}{llllll}\text { Districts } & \begin{array}{l}\text { Training of } \\ \text { Extended-Bioaab } \\ \text { solution }\end{array} & \begin{array}{l}\text { Total (\%) } \\ \text { No (\%) }\end{array} & \begin{array}{l}\text { If yes (\%) training } \\ \text { provided by }\end{array} \\ & 2(1.6) & 25(19.5) & 27(21.1) & 25(19.5) & 0 \\ \text { Swat } & 25 \text { Ext. Deptt. } & \begin{array}{l}\text { Any } \\ \text { other }\end{array} \\ \text { Malakand } & 0(0) & 30(23.4) & 30(23.4) & 30(23.4) & 0 \\ \text { Lower Dir } & 1(.8) & 23(18) & 24(18.8) & 23(18) & 0 \\ \text { Upper Dir } & 0(0) & 13(10.2) & 13(10.2) & 13(10.2) & 0 \\ \text { Buner } & 2(1.6) & 22(17.2) & 24(18.8) & 22(17.2) & 0 \\ \text { Shangla } & 0(0) & 10(7.8) & 10(7.8) & 10(7.8) & 0 \\ \text { Total } & 5(3.9) & 123(96.1) & 128(100) & 123(96.1) & 0\end{array}$

\section{Extended-Bioaab Solution Training}

The BM-Bioaab purchased from market is the " $\mathrm{Ba}$ sic BM-Bioaab" and the one prepared by farmers by extending the Basic Bioaab is the "Extended BM-Bioaab" (Hussain et al., 2002). To extend one liter Basic Bioaab, take 30 liter volume clean plastic can and add 20 liter water to it and now put one liter molasses to water and mix it thoroughly. Now add one liter Basic Bioaab, shake it and close the lid to place the can for three days in a room. After every 24 hours open the lid to release the gas. Now 22 liters of Extended-Bioaab prepared by you is ready, which is as influential as Basic Bioaab and can be used within two weeks (http://www.pakissan.com). Table 2 presents data regarding training for preparing Extended-Bioaab and it indicates that only 5 (3.9\%) farmers had no training regarding preparation of Extended-Bioaab, whereas 123 (96.1\%) farmers were trained by extension department for preparing Extended-Bioaab solution which upgraded their knowledge and skills. Ali and Haider (2012) obtained similar results where all respondents got training from extension workers and claimed that the trainings helped them in updating their knowledge about modern technology.

\section{Reason for opting EM technology through fermenter}

Numerous research studies have established wide range beneficial effects resulting from the use of EM technology which includes increase crop yield, better fertilizer use efficiency, enhanced soil physical properties and EM's synergistic effect on nutrient uptake etc. (Asmatullah et al., 2019; Prashanth and Reddy, 2014: Minami and Higa, 1994; Poonyarit et al., 1993). Table 3 represents reasons for adopting EM technology through fermenter which includes decrease in fertilizer usage, use FYM effectively, increase production and yield by minimizing production cost.

Table 3: Farmers reasons for opting EM technology through Fermenter.

\section{Districts Reason for opting EM technology through Fermenter}

Decrease Use FYM Increase Minimize the Use of effectively production production Fertilizers No. (\%) and yield No. cost No. (\%) No. (\%) (\%)

$\begin{array}{lllll}\text { Swat } & 27(21.1) & 27(21.1) & 27(21.1) & 27(21.1) \\ \text { Malakand } & 30(23.4) & 30(23.4) & 30(23.4) & 30(23.4) \\ \text { Lower dir } & 24(18.8) & 24(18.8) & 24(18.8) & 24(18.8) \\ \text { Upper dir } & 13(10.2) & 13(10.2) & 13(10.2) & 13(10.2) \\ \text { Buner } & 24(18.8) & 24(18.8) & 24(18.8) & 24(18.8) \\ \text { Shangla } & 10(7.8) & 10(7.8) & 10(7.8) & 10(7.8) \\ \text { Total } & 128(100) & 128(100) & 128(100) & 128(100)\end{array}$

Fertilizers use of selected crops, before and after use of EM technology through fermenter

The concentration of NPK in soil is increased when $\mathrm{EM}$ is combined with organic wastes and synthetic fertilizer and maximum increases for $\mathrm{N}$ (48.5\%), $\mathrm{P}(60 \%)$ and K (90\%) was recorded when compost + EM, poultry manure + EM and pressmud + EM were used instead of no EM treatments (Karim et al., 1993). They further commented that the increasing trend might be due to enhanced microbial activity by EM resulting release and availability of nutrients to plants. Primarily, EM causes quick mineralization of organic materials to release nutrients resultantly improving soil fertility (Namasivayam and Kirithiga, 2010). Prabu et al. (2003) also mention organic farming system as the best possible solution to overcome use of high cost synthetic inorganic fertilizer. 
Table 4: Paired sample t-test showing effect of EM technology on fertilizer use of selected crops.

\begin{tabular}{llllllll} 
Crops & \multicolumn{3}{l}{$\begin{array}{l}\text { Effect of EM Application on Fertilizer Use } \\
\text { Before }\end{array}$} & \multicolumn{7}{c}{ After } & Mean Differences & t-value & (p-value) \\
& Mean & Standard Error & Mean & Standard Error & & & \\
Tomato & 5.04 & .142 & 2.89 & .099 & 2.151 & 27.301 & .000 \\
Onion & 4.52 & .104 & 2.42 & 0.54 & 2.103 & 24.586 & .000 \\
Wheat & 6.30 & .117 & 5.30 & .122 & 1.000 & 14.647 & .000
\end{tabular}

Table 5: Paired sample t-test showing effect of EM technology on number of irrigations of selected crops.

\begin{tabular}{llllllll} 
Crops & \multicolumn{2}{l}{ Effect of EM Application on Number of Irrigations } & Mean Differences & t-value & (p-value) \\
& Before & After & & & \\
& Mean & Standard Error & Mean & Standard Error \\
Tomato & 11.66 & .100 & 10.15 & 0.69 & 1.509 & 22.868 & .000 \\
Onion & 9.28 & 0.84 & 7.60 & .112 & 1.685 & 27.311 & .000 \\
Wheat & 5.45 & .120 & 4.25 & .136 & 1.200 & 15.362 & .000
\end{tabular}

To indicate the effect of EM technology on fertilizer use of selected crops, a paired sample t-test is used. Table 4 reveals a highly significant $(\mathrm{p} \leq 0.01)$ difference in fertilizer usage for tomato after the use of EM technology through fermenter and on average recorded a decrease of 2.151 bags ha ${ }^{-1}$. Likewise, highly significant difference $(p \leq 0.01)$ in fertilizer use was observed in onion and wheat after use of EM technology. Onion crop showed average decrease of 2.103 bags ha ${ }^{-1}$ while wheat had 1.00 bags ha $^{-1}$ decrease in fertilizer use. Results deduce that appropriate use of EM technology, can decrease inorganic fertilizer use and thus the null hypothesis is rejected. In Thailand same results were reported for a rice experiment by Poonyarit et al. (1993). They recorded that one-half recommended rate of NPK synthetic fertilizer when applied with EM gave rice yield equal to that achieved with full dose of chemical fertilizer. Parallel results were observed by Karim et al. (1993) in Bangladesh where one half recommended rate of synthetic fertilizer + EM were applied instead of full dose of fertilizer. Jalal et al. (2020) also observed increase in maize yield and better nitrogen content with the application of beneficial microbes with organic and inorganic fertilizer in a 50:50 ratio.

Number of irrigation of selected crops, before and after use of EM technology through fermenter

A paired sample t-test was carried out to highlight the outcome of EM application on number of irrigation of selected crops. Results in Table 5 reveal a highly significant difference $(p \leq 0.01)$ in number of irrigation for tomato after EM application through fermenter and showed 1.509 decrease in number of irrigation on average. Likewise, highly significant difference $(p \leq 0.01)$ in number of irrigation was observed in onion and wheat after EM technology. Onion recorded on average 1.685 while 1.200 decreases in number of irrigations were observed in wheat. Hence it was accomplished that use of EM through fermenter decrease the number of irrigation of selected crops as water holding capacity of soil is enhanced due to addition of EM to the field. Thus we reject the null hypothesis of no difference in number of irrigations of selected crops after EM use through fermenter. Li et al. (2021) and Strunecky et al. (2021) reported that biochar has the capability to increase water retention ability of soil and thus can improve crop productivity.

\section{Adding FYM through fermenter}

It is clear from Figure 1 that majority farmers (116) reported adding FYM to the field without fermenter as time consuming while only 12 farmers reported adding FYM through fermenter as time consuming. The reason behind it might be that mostly farmers of the area have limited number of livestock and has difficulty in bringing FYM manure from far flung areas which is time consuming. In addition, 116 farmers reported adding FYM and its incorporation in the fields as much laborious without fermenter and opined that without fermenter FYM is not properly incorporated and distributed in the field. Fermenter is the best method for applying FYM was reported by 116 farmers against 12 farmers who reported adding FYM without fermenter as the best method. However, 12 and 55 farmers reported FYM applica- 
tion through fermenter as time wasting and laborious whereas, 43 farmers responded unequal distribution through fermenter technology.

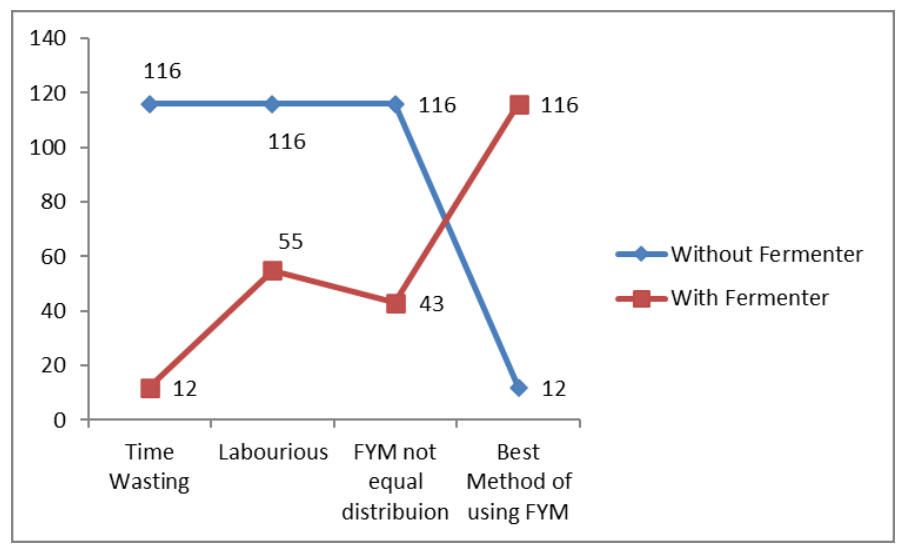

Figure 1: Line Chart Graph of Differences of Adding FYM With and Without Fermenter.

\section{Conclusions and Recommendations}

The main focus of the study was to highlight the effect and use of EM technology on fertilizer use and number of irrigation on the selected crops in the study area. It was accomplished that the extension department provided EM-Bioaab to the farmers and motivated them to adopt it and also provided training to the farmers in making Bioaab solution. The use of EM-Technology through fermenter minimized the fertilizer use and numbers of irrigation were also decreased in selected crops. Adding FYM through fermenter saved time, less laborious and distributes FYM equally in the field resulting better soil structure and enhanced water holding capacity. Organic farming should be promoted to control the unwise use of synthetic fertilizer. It is recommended that extension department should promote and impart EM technology to the farming community of the province to achieve the benefits of increased production, decrease in fertilizer usage and number of irrigations and to minimize environmental and health hazards. Agriculture extension department should organize more training regarding use of use EM-Technology and FYM through fermenter in other areas of the province as well. Extension and research institutions should motivate and aware the farmers about the advantages of organic farming. The study recommends adoption of EM technology; therefore comprehensive policy should be made and implemented by the government so the farmers could achieve its benefits.

\section{Novelty Statement}

This study provides insights into the benefits of organic farming especially the use of EM technology through fermenter and its effect on application of fertilizer and number of irrigations on selected crops.

\section{Author's Contribution}

Ayesha Khan: Planned, supervised and wrote the manuscript also interpreted the results.

Asmatullah: Carried out the research, collected the field data and performed the analysis.

Urooba Pervaiz and Mahmood Iqbal: Helped in statistical analysis.

Khalid Nawab: Performed language editing.

\section{Conflict of interest}

The authors have declared no conflict of interest.

\section{References}

Alam, S.M., S.A. Shah, S. Ali and M.M. Iqbal. 2005. Yield and phosphorus uptake by crops as influenced by chemical fertilizer and integrated use of industrial by products. Songklanakarin J. Sci. Technol., 27 (1): 9-16.

Ali, M. and M.S. Haider. 2012. An analysis of Farmer Field School (FFS) as a Potential Source of Advanced Technology Dissemination among the Farmers of District Faisalabad, Pakistan. Ontario Int. J. Sustain. Dev., 03:01.

Asmatullah, A. Khan, U. Perviaz and R. Ullah. 2019. Effects of fermenter technology on the yield of various crops in Khyber Pakhtunkhwa Pakistan. Asian J. Agric. Ext. Econ. Soc., 31 (1):1-6. https://doi.org/10.9734/ajaees/2019/ v31i130122

Bhoyar,M.G.,O.Gavkare, S. V.Ghumare, K. Babita and D. S. Kachawaya. 2013. E. M. Technology and it's Impact in Organic Horticulture. Pop. Kheti. 1(4):107-112.

Ayoola, O.T. and E.A. Makinde. 2007. Complementary Organic and Inorganic Fertilizer Application: Influence on Growth and Yield of Cassava/Maize/Melon Intercrop with a Relayed Cowpea. Aust. J. Basic Appl. Sci., 1(3): 187-192.

Braun, H. and R.N. Roy. 1983. Maximizing the efficiency of mineral fertilizers. Proceedings of a Symposium on Efficient Use of Fertilizers in 
Agriculture. Dev. Plant Soil Sci., 10:251-273.

Draft (PCI). 2013-14. Establishment and dissemination of fermentation technology for organic farming in Khyber Pakhtunkhwa. Agric. Ext. Dep., pp. 2-8.

Erisman, J.W., D. Vries, W. Kros, J. Oenema, O.V. Eerden, L. Zeljts and S.M. Smeulders. 2001. An outlook for an integrated nitrogen policy. Environ. Sci. Policy, 4: 87-95. https://doi. org/10.1016/S1462-9011(00)00116-7

Gomiero, T., D. Pimental and M.G. Paoletti. 2011. Environmental impact of different agricultural management practices: Conventional vs. organic agriculture. Crit. Rev. Plant Sci., 30 (1):95-124. https://doi.org/10.1080/07352689 .2011 .554355

Higa, T. 1991. Effective microorganisms: A Biotechnology for Mankind. Pp: 8-14. In Parr, J. F., S.B. Hornick and C. E. Whiteman (eds.) Proceedings of the First International Conference on Kyusei Nature Farming. U. S. Department of Agriculture, Washington, D.C., USA.

Higa, T. 2000. What is EM technology? EM World J., 1:1-6.

Higa, T. and G.N. Wididana. 1991. The concept and theory of Effective Microorganisms. pp. 118-124. In J. F. Parr, S. B. Hornick and C. E. Whitman (ed.). Proceedings of the First International Conference on Kyusei Nature Farming. U. S. Department of Agriculture, Washington, D.C., USA. http://www.Pakissan. com. Nutrient cycling and (EM) EffectiveMicroorganism technology. Hadi Bux Leghari. Hussain, T., A.D. Anjum and J. Tahir. 2002. Technology of Beneficial Microorganisms. Nat. Farm. Environ., 3: 1-14.

Hussain, T., S. Muhammad and G. Jilani. 1992. Prospects of natural agriculture in Pakistan. Proceedings of the third national congress of soil science. March 20-22, 1990, Lahore, Pakistan. pp. 112-122.

Jalal, A., K. Azeem, M.C.M.T. Filho and A. Khan. 2020. Enhancing soil properties and maize yield through organic and inorganic nitrogen and diazotropic bacteria. In: Sustain. Crop Prod. IntechOpen. Available at: https:// www.intechopen.com/books/suitable-cropproduction/enhancing-soil-properties-andmaize-yield-through-organic-and-inorganicnitrogen-and-diazotrophic-ba https://doi. org/10.5772/intechopen.92032

Javaid. A. and R. Bajwa. 2010. Field evaluation of Effective Microorganisms (EM) application for growth, nodulation, and nutrition of Mung Bean. Turk J. Agric., 4(35): 443-452.

Karim, A.J.M.S., A.R. Chowdhury and J. Haider. 1993. Effect of manuring and Effective Microorganisms (EM) on physico-chemical properties of soil and yield of wheat. Pp. 27-39. Proceedings of the First International APNAN Conference on EM Technology, June 22-25, 1992. Saraburi, Thailand.

Khanam, M., M.M. Rahman and M.R. Islam. 2001. Effect of Manures and Fertilizers on the Growth and Yield of BRRI Dhan 30. Pak. J. Biol. Sci., 4: 172-174. https://doi.org/10.3923/ pjbs.2001.172.174

Kumar, A. and J.P. Verma. 2019. The role of microbes to improve crop productivity and soil health. In: Ecological Wisdom Inspired Restoration Engineering. Singapore: Springer, pp. 249-265. https://doi.org/10.1007/978-98113-0149-0_14

Li, L., Y.J. Zhang, A. Novak, Y. Yang and J. Wang. 2021. Role of biochar in improving sandy soil water retention and resilience to drought. Water, 13(4): 407. https://doi.org/10.3390/ w13040407

Meihoefer, H. 2000. The Use of Effective Microorganisms (EM) in Organic Waste Management. San Francisco State University. Available at http://www.emtrading.com accessed on 24/1/2016

Minami, T. and T. Higa. 1994. Kyusei Nature Farming in Japan: Effect of EM on the yield of paddy rice. p. 97-102. In J. F. Parr, S. B. Hornick and M. E. Simpson (ed.). Proceedings of the Second International Conference on Kyusei Nature Farming. U.S. Department of Agriculture, Washington, D.C., USA.

Muhammad, H., M.A. Zaman, S.K. Khalil and Z. Shah. 2014. Effects of Beneficial Microbes (BM) on the Efficiency of Organic and Inorganic N Fertilizers on Wheat Crop. Sarhad J. Agric., 30 (1): 7-14.

Namasivayam, S.K.R. and Kirithiga. 2010. Effect of formulation of effective microorganism (EM) on post treatment persistence, microbial density and soil macronutrients. Recent Res. Sci. Technol., 2(5): 102-106.

Prashanth, P. and M.J.M. Reddy. 2014. Factors 
influencing the adoption of organic farming by the farmers of Karimnagar District of Andhra Pradesh. Int. J. Farm Sci., 2: 123-128.

Poonyarit, M., W. Chaitep, N. Muangprasert, J. Hoykaw and S. Ponput. 1993. The use of Effective Microorganisms with chemical fertilizers on rice production. pp. 84-99. Proceedings of the First International APNAN Conference on EM Technology. June 22-25, 1992, Saraburi, Thailand.

Prabu, T., P.R. Narwadkar, A.K. Sanindranath and M. Rafi. 2003. Effect of Integrated Nutrient Management on Growth and Yield of Okra cv. Parbhani Kranti. Orissa J. Hort., 31: 17-21.

Rashid, M.I., L.H. Mujawar, T. Shahzad, T. Almeelbi, I.M.I. Islamil and M. Oves. 2016. Bacteria and fungi can contribute to nutrients bioavailability and aggregate formation in degraded soils. Microbiol. Res., 183:26-41. https://doi.org/10.1016/j.micres.2015.11.007

Shaharoona, B. and M. Arshad. 2003. Composting:

A Dual Fact Technology for Sustainable Agriculture and Environments. Available at http:/www.pakissan.com/english/issues/ composting.shtml. Accessed on November 24, 2020.

Shaheen S., M. Khan, M. J. Khan, S. Jilani, Z.
Bibi, M. Munir and M. Kiran. 2017. Effective Microorganisms (EM) co-applied with organic wastes and NPK stimulate the growth, yield and quality of spinach (Spinacia oleracea L.). Sarhad J. Agric., 33(1): 30-41.

Strunecky, O., S. Shreedhar, L. Kolar and A. Marouskova. 2021. Changes in soil water retention following biochar amendment. Energy sources, Part A: Recovery, Utilization, and Environomental Effects. https://doi.org/1 0.1080/15567036.2021.1916652

Suresh, K.D., G. Sneh, K.K. Krishn and C.M. Mool. 2004. Microbial Biomass Carbon and Microbial Activities of Soils Receiving Chemical Fertilizers and Organic Amendments. Arch. Agron. Soil Sci., 50: 7-641. https://doi. org/10.1080/08927010400011294

Whalen, J.K., H. Quancai and L. Aiguo. 2003. Compost Applications Increase Water-Stable Aggregates in Conventional and No-Tillage Systems. Soil Sci. Soc. Am. J., 67: 1842-1847. https://doi.org/10.2136/sssaj2003.1842

Xiao, C., M. Fauci, D.F. Bezdicek, W.T. Mckean and W.L. Pan. 2006. Soil Microbial Responses to Potassium-Based Black Liquor from Straw Pulping. Soil Sci. Soc. Am. J., 70 (1): 72-77. https://doi.org/10.2136/sssaj2004.0339 